Original Research
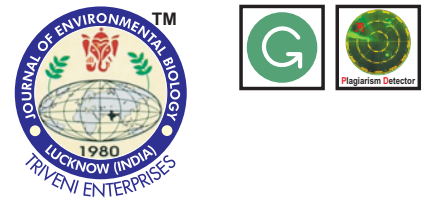

\title{
Antifungal properties of Beauveria bassiana strains against Fusarium oxysporum f. sp. Iycopersici race 3 in tomato crop
}

\section{Authors Info}

J.M. Culebro-Ricaldi', V.M. RuízValdiviezo', M.A. Rodríguez-Mendiola', M.E. Ávila-Miranda', F.A. GutiérrezMiceli', R.I. Cruz-Rodríguez',

L. Dendooven ${ }^{3}$ and J. A. Montes-Molina

'Laboratory of Biotechnology, Instituto Tecnológico de Tuxtla Gutiérrez, Carretera Panamericana Km 1080, C.P. 29050.Tuxtla Gutiérrez, México

${ }^{2}$ Instituto Tecnológico de Tlajomulco de Zuñiga, Km 10 carr Tlajomulco - San Miguel Cuyutlan, C.P. 45640

Tlajomulco de Zúñiga, México

${ }^{3}$ ABACUS, Cinvestav, Av. Instituto Politécnico Nacional 2508, C.P. 07360 , México D.F., México

*Corresponding Author Email : monttes21@hotmail.com

Key words

Antagonism,

Beauveria bassiana,

Enthomopathogenic fungus,

Fusarium oxysporum,

Plant growth promotion

Publication Info

Paper received : 19.07.2016

Revised received : 16.12 .2016

Re-revised received : 24.01.2017

Accepted : 15.02.2017

\section{Abstract}

Aim : Entomopathogenic fungus, Beauveria bassiana from different geographic regions, i.e. Coahuila, Nuevo Leon and Tabasco were assessed for their in vitro and in vivo antagonistic activity in tomato Solanum lycopersicum L., against soil borne disease, Fusarium oxysporum f. sp. Iycopersici race 3 .

Methodology : The strains were assessed in vitro (dual culture technique, lytic enzyme production and inhibition potency of culture filtrates). Strain 1215 was used to control F. oxysporum f. sp. lycopersici race 3 in tomato plants in vivo. The strain was applied to soil, foliar sprayed or stem injected, and plant development determined.

Results : These strains inhibited pathogen growth collapsing the mycelium, but only $B$. bassiana strain 1215 inhibited growth of $F$. oxysporum f. sp. lycopersici race 3 efficiently with $72 \%$ when applied in to the medium two days earlier. Lytic enzyme inhibited up to $21 \%$ of the growth of soil borne fungal pathogen in vitro. Application of $B$. bassiana strain 1215 to soil decreased by 1.4 the plant index disease without any adverse effect on plantheight and root development.

Interpretation : Overall, the most efficient was $B$. bassiana strain 1215, which reduced the growth of $F$. oxysporum f. sp. Iycopersici race 3 in vitro and decrease disease development in vivo without any adverse effect on plant height and root development and can be used as biological control agent against certain fungal pathogens.

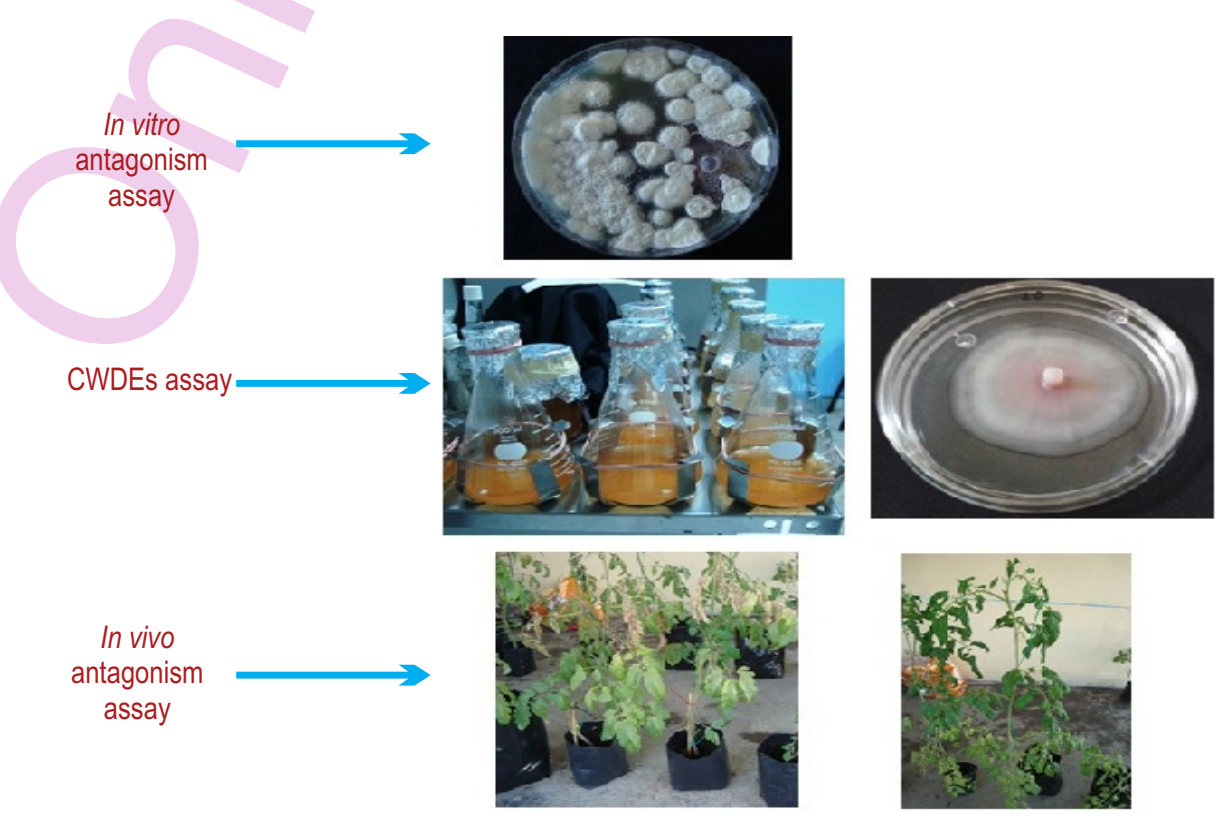




\section{Introduction}

Tomato (Solanum lycopersicum) in Chiapas (Mexico) is an important vegetable crop with annual production of $2.5 \times 10^{5}$ tons (INEGI, 2011). However, tomato yield is low due to its susceptibility to several pathogenic fungi, bacteria, viruses and nematodes (Barone and Frusciante, 2007). The soil-borne Fusarium oxysporum is one of the most devastating disease ranking fifth in fungal plant pathogens, which can reduce tomato production significantly (Dean et al., 2012). Different formae speciales (f. sp.) exist for F. oxysporum with f. sp. lycopersici infecting mainly tomatoes. Tomato production is often reduced by 30 to $40 \%$, however, sometimes it may reach up to $80 \%$ (Nirmaladevi et al., 2016). Three physiological races (1, 2 and 3) of pathogen specify are distinguished by their specific pathogenicity to tomato cultivars. They invade the root epidermis, extend into the vascular tissues and colonize the xylem vessels. Disease symptoms appear as a result of severs water stress, mainly due to vessel clogging (Nirmaladevi et al., 2016). Use of resistant cultivars is the most reliable method for disease management. However, no commercial cultivar is available with adequate levels of resistance to $F$. oxysporum f. sp. lycopersici and management thus, relies primarily on chemical control (Vos et al. 2014). In recent years, different studies have shown that entomopathogenic fungi, such Beauveria bassiana, are useful biocontrol agents against $F$. oxysporum due to their ability to infect a wide range of insect pess and the production of toxic secondary metabolites (Sung et al., 2007). B. bassiana has the potential to limit the growth of plants pathogens, such Botrytis cinerea (Bark et al. 1996), Rhizoctonia solani (Ownley et al., 2008a) and Alternaria porri (Gothandapani et al. 2014). Isolates of $B$. bassiana have been used in the greenhouse against basal rot of onion (Allium cepa L.) caused by F. oxysporum f. sp. cepae, and they were found to reduce the infection significantly (Flori and Roberti, 1993). This fungus also colonizes a variety of cultivated plants, such Theobroma cacao (Posada and Vega, 2005), Musa spp. (Akello et al., 2007), Solanum lycopersicum (Ownley et al., 2008a), Gossypium hirsutum (Gurulingappa et al., 2010; Lopez and Sword, 2015), Pinus radiata (Brownbridge et al., 2012), Papaver somniferum (Quesada-Moraga et al., 2009) and Manihot esculenta (Greenfield et al., 2016). The mechanism of antagonism of $B$. bassiana includes antibiosis (Vesely and Koubova, 1994; Bark et al., 1996), competition (Ownley et al., 2004) and induced systemic resistance (Ownley et al., 2008b). Nevertheless, studies on enzymes production, secondary metabolites or antibiotics responsible on mycelial growth inhibition of pathogenic fungi is meagre. In view of the above, the present study was carried out to control pathogens in tomato plants, $B$. bassiana was tested as a biocontrol agent of $F$. oxysporum f. sp. lycopersici race 3 . First, the antagonistic capacity of three different strains of $B$. bassiana against $F$. oxysporum f. $\mathrm{sp}$. lycopersici race 3 was determined in vitro and later, the antagonistic capacity of the most promising strain of $B$. bassiana against $F$. oxysporum $f$. sp. lycopersici race 3 was undertaken in tomato plants in vivo.

\section{Materials and Methods}

Fungal microorganisms : Three strains of $B$. bassiana (19, 1205 and 1215) and one strain of F. oxysporum f. sp. lycopersici race 3 (Fol3) were studied. The 5.8S rRNA gene sequence of strains 19,1205 , and 1215 of $B$. bassiana were deposited in the GenBank database under the accession numbers KX232464, KX232465 and KX232466, respectively, while that of strain Fo/3 of $F$. oxysporum f. sp. lycopersici race 3 under accession number $\mathrm{KX} 232463$. For all the in vitro experiments, disks $(5 \mathrm{~mm})$ from the edge of growing fungal colonies were used.

In vitro assays : Antagonistic activity: In the first experiment, each strain of $B$. bassiana was grown as dual culture with $F$. oxysporum f. sp. lycopersici race 3. Agar disks with a strain of $B$. bassiana were placed separately in sterile plastic round $9 \mathrm{~cm}$ Petri dishes containing $15 \mathrm{ml}$ of PDA medium. After two days, the pathogen was placed equidistantly at the opposite side of the antagonist and incubated at $28^{\circ} \mathrm{C}$ for 12 days in darkness. Colony radii of the phytopathogenic fungi were measured twice a day for 12 days (Annes et al., 2010). This procedure was repeated five times for each strain.

In the second experiment, Agar disks each with a strain of B. bassiana were placed separately in a Petri dish equidistantly at the opposite side of the pathogen at the same time and incubated at $28^{\circ} \mathrm{C}$ for 12 days. Petri dishes containing only a disk with the phytopathogenic fungi served as control (Annes et al., 2010). Antagonism was classified as suggested by Mbarga et al. (2012). Grade 1 was obtained when the antagonist covered the entire surface of the medium; 1.5 grade when the antagonist covered $87.5 \%$ of the medium surface; grade 2 when the antagonist covered approximately $67 \%$ of the medium surface; 2.5 grade when the antagonist covered approximately $62.5 \%$ of the medium surface, grade 3 when the antagonist covered approximately $50 \%$ of the medium surface, grade 4 when the antagonist covered approximately $33.3 \%$ of the medium surface; grade 5 when the antagonist did not grow and the pathogen covered the entire medium surface.

Antifungal activity of extracellular metabolites : Four disks of $5 \mathrm{~mm}$ diameter were cut from the growing tip of 15-day old culture of each $B$. bassiana strain with the help of a cork borer, added to a flask containing $50 \mathrm{ml}$ of liquid medium and incubated in a rotatory shaker at $150 \mathrm{rpm}$ and $28^{\circ} \mathrm{C}$ for eight days. The medium was prepared as described by Rajeswari (2015). Briefly, $50 \mathrm{ml}$ sterilized Czapek's liquid media $\left(\mathrm{MgSO}_{4} 7 \mathrm{H}_{2} \mathrm{O}, 0.5 \mathrm{gl}^{-1}, \mathrm{KCl} 0.5\right.$ $\mathrm{gl}^{-1}, \mathrm{NaNO}_{3}, 3 \mathrm{gl}^{-1} ; \mathrm{K}_{2} \mathrm{HPO}_{4}, 1 \mathrm{gl}^{-1} ; \mathrm{FeSO}_{4}, 0.01 \mathrm{gl}^{-1} ; \mathrm{V} 8$ juice, $200 \mathrm{ml}$, adjusted to $1200 \mathrm{ml}$ ) in a $250 \mathrm{ml}$ Erlenmeyer flasks and supplemented with crab shell chitin $(1 \% \mathrm{w} / \mathrm{v})$ as carbon source. The mycelium was harvested by filtering the solution through a Whatman No. 1 filter paper placed on a Buchner funnel under vacum. Cells were removed by centrifugation at $8,000 \mathrm{rpm}$ at $4^{\circ} \mathrm{C}$ 
for $20 \mathrm{~min}$ and the supernatant was recovered. Growth inhibitory effects of the extracellular metabolites were determined by using the radial growth inhibition assay and fungal growth inhibition was expressed as the percentage of radial growth inhibition in comparison with control (Prapagdee et al., 2007). In the control treatment, only one disk of the phytopathogenic fungi was placed in the middle of the Petri dish containing PDA medium and was added with sterile distilled water. This procedure was repeated three times for each strain at different days of incubation $(2,4,6$ and 8).

Determination of enzyme activity : Activity of chitinase and $\beta-1$, 3 -glucanase was quantified in the extracellular medium of $B$. bassiana as described by Reissig et al., (1957) and Zheng and Wozniak (1997). Protein concentration was estimated by the protein kit (Bio-Rad), according to the method described by Bradford, using Bovine Serum Albumine as a standard. The whole procedure was performed in triplicate.

In vivo study : B. bassiana strain that exhibited the best antagonistic effect against $F$. oxysporum $\mathrm{f}$. sp. lycopersici race 3 was used in the in vivo study with tomato plants. The $B$. bassiana strain 1215 was cultured on potato dextrose agar media at $28 \pm 2^{\circ} \mathrm{C}$ for 15 days. Four disks of five $\mathrm{mm}$ diameter were cut and transferred into $50 \mathrm{ml}$ flasks containing liquid medium (Rajeswari, 2015). The flasks were placed on a rotary shaker at $28^{\circ} \mathrm{C}$ and 150 rpm for eight days (Ahmed Idris et al., 2007). Spores were extracted and quantified in a Neubauer chamber. The conidial suspension of $B$. bassiana was adjusted to a spore concentration of $1 \times 10^{7}$ conidia $\mathrm{m}^{-1}$ with sterile distilled water.

Tomato plants were cultivated following the method of Montes-Molina et al. (2014). Commercial seeds of tomato (Solanum lycopersicum L.) var. Rio Fuego susceptible to $F$. oxysporum f. sp. Iycopersici race 3 were sown in plastic containers (14.8 cm long $11.0 \mathrm{~cm}$ wide) filled with sterile peat moss and kept in a growth chamber. After 25 days, tomato seedlings were inoculated with a conidial suspension of $B$. bassiana and one week later the plants were inoculated, with 10 $\mathrm{ml}$ of $F$. oxysporum f. sp. lycopersici $\left(1 \times 10^{5}\right.$ conidia $\left.\mathrm{ml}^{-1}\right)$ suspension and kept in greenhouse with a photoperiod of $12 \mathrm{hr}$ and daily average temperature of $32 \pm 2^{\circ} \mathrm{C}$ for 25 days. Each plant was supplied with $75 \mathrm{~kg} \cdot \mathrm{ha}^{-1}$ urea, per plant approximately $1.2 \mathrm{~g}$, 15 and 45 days after emergence and $90 \mathrm{~kg} \cdot{ }^{-1} \mathrm{w}^{-1}$ with triple $17(17 \%$ $\mathrm{N}, 17 \% \mathrm{Pas}_{2} \mathrm{O}_{5}$ and $17 \% \mathrm{Kas} \mathrm{K}_{2} \mathrm{O}$ ), per plant approximately $1 \mathrm{~g}$, 15 days after emergence. The plants were watered as and when needed during experimentation and were inoculated every $5^{\text {th }}$ day with the antagonistic strain.

The antagonist was applied in three different ways to tomato plants, i.e., foliar spray, stem injection and soil application. Application rate and inoculation of tomato plants with $B$. bassiana strain 1215 was done as per method described by Posada et al. (2007). In foliar spray, $8 \mathrm{ml}$ of suspension $\left(1 \times 10^{7}\right.$ conidia $\left.\mathrm{ml}^{-1}\right)$ was directly sprayed on leaves with the help of an atomizer. The planted soil surface was covered with plastic sheet to avoid leaching of spray solution in potted soil. In stem injection, a BD Ultra Fine ${ }^{\mathrm{TM}}$ syringe with sterile hypodermic needle $31 \mathrm{G}$ was used to inject $0.2 \mathrm{ml}$ suspension $\left(1 \times 10^{7}\right.$ conidia $\left.\mathrm{ml}^{-1}\right)$ into the stem. In soil application, $8 \mathrm{ml}$ suspension $\left(1 \times 10^{7}\right.$ conidia $\left.\mathrm{ml}^{-1}\right)$ was sprayed directly on the soil surface of each pot. In control treatment, sterile water was used instead of conidial suspension. One screen house experiment was laid out in randomized block design with 140 experimental units, where factors evaluated were: $B$. bassiana method of application (foliar, stem and soil) and time $(5,10,15,20,25$ days). Control treatments used the same method of application of $B$. bassiana and one treatment without fungus. The whole procedure was performed in quadruplicate. All the methods were same as described in the previous experiment.

At 5 -day interval for 25 days after inoculation, four containers with tomato plants of each treatment were taken to laboratory. The tomato plants were taken out from the container and the soil washed from the roots. Tomato plants were studies for plant height $(\mathrm{cm})$, root length $(\mathrm{cm})$, dry root weight $(\mathrm{g})$, dry leaf weight $(\mathrm{g})$ and disease severity. The disease development was assessed on three replicated plants per treatment using a numerical scale of $0-3$; where 0 is healthy; 1 is slight infection and yellowing of leaves; 2 is severe wilting and yellowing of leaves; 3 is dead plants (Chandel et al., 2010).

Statistical analysis : Data were subjected to the analysis of variance and the means were compared with a Tukey's multiple range test $(P<0.05)$.

\section{Results and Discussion}

The antagonistism of the $B$. bassiana strains towards $F$. oxysporum was determined in vitro by the dual culture technique (Rahman et al., 2009) and the bioassays showed an inefficient antagonism when both were applied to the medium at the same time (Table 1). Inhibition efficiency ranged from $22 \%$ (strain Bb19) to $31 \%$ (strain 1215). Contact between the hyphae of strain 1215 and $F$. oxysporum occurred after 7 days. However, the radial growth of $B$. bassiana strains was slower than Fusarium.

The growth of phytopathogenic fungus was slower when B. bassiana strains were applied to the medium two days earlier to F. oxysporum as compared to simultaneous inoculation and both organism came in contact with each other on $4^{\text {th }}$ day (Table 1 ). None of the antagonistic strains did overgrow the pathogen. $B$. bassiana strain 1215 was the most efficient and showed a $72 \%$ inhibition compared to strains $1205(61 \%)$ and Bb-19 (55\%). The results indicated that different $B$. bassiana strains had variable biocontrol potential. Dubey et al. (2007) reported that the antagonistic capacity of Trichoderma varied from species to species and isolate to isolate; thus growth rate is an important 
Table 1 : In vitro bioefficacy of $B$. bassiana strains against Fusarium oxysporum f.sp. lycopersici race 3

\begin{tabular}{lcc}
\hline & Application of B. bassiana to the medium 2 days before $F$. oxysporum \\
\hline Strains & Hyphae contact (days) & Growth inhibition (\%) \\
\cline { 2 - 3 } 1215 & $4^{\mathrm{a}} \pm 0.4^{\mathrm{b}} \mathrm{A}^{\mathrm{c}}$ & $72 \pm 0.5 \mathrm{~A}$ \\
1205 & $4 \pm 0.5 \mathrm{~A}$ & $61 \pm 0.6 \mathrm{~B}$ \\
Bb19 $_{\text {MSD }^{\mathrm{d}}}$ & $4 \pm 0.5 \mathrm{~A}$ & $55 \pm 0.6 \mathrm{C}$ \\
\hline \multicolumn{3}{c}{ Application of B. bassiana and $\boldsymbol{F}$. oxysporum to the medium at same time } \\
\hline 1215 & 0.2 & $31 \pm 0.5 \mathrm{~A}$ \\
1205 & $7 \pm 0.7 \mathrm{C}$ & $24 \pm 0.6 \mathrm{~B}$ \\
Bb19 & $8 \pm 0.2 \mathrm{~B}$ & $22 \pm 0.9 \mathrm{C}$ \\
MSD & $9 \pm 0.4 \mathrm{~A}$ & 0.6 \\
\hline
\end{tabular}

${ }^{a}$ Values are means of five replicates, ${ }^{b}$ Standard deviation of the mean, ${ }^{c}$ Values with the same captital letter are not significantly different between strains, i.e., within the columns at $\mathrm{P}<0.05,{ }^{\mathrm{d}} \mathrm{MSD}$ : Minimum significant difference at $\mathrm{P}<0.05$

Table 2: Extracellular enzymes production potency of $B$. bassiana strains

\begin{tabular}{|c|c|c|c|c|c|c|c|c|}
\hline \multicolumn{2}{|l|}{ Strains } & \multicolumn{3}{|c|}{$\begin{array}{l}\beta-1,3-G \text { lucanase } \\
\text { (pkat } \mathrm{ml}^{-1} \text { ) } \\
\text { Days }\end{array}$} & \multirow[b]{2}{*}{2} & \multicolumn{2}{|l|}{$\begin{array}{l}\text { Chitinase } \\
\text { (pkat ml }^{-1} \text { ) } \\
\text { Days }\end{array}$} & \multirow[b]{2}{*}{8} \\
\hline & 2 & 4 & 6 & 8 & & 4 & 6 & \\
\hline 1205 & $133^{a} \pm 2^{b} B^{c}$ & $233 \pm 1 \mathrm{~A}$ & $176 \pm 1 \mathrm{~B}$ & $89 \pm 1 C$ & $28 \pm 1 B$ & $154 \pm 1 \mathrm{~A}$ & $29 \pm 1 B$ & $38 \pm 1 \mathrm{~B}$ \\
\hline 1215 & $167 \pm 2 \mathrm{~A}$ & $126 \pm 1 \mathrm{C}$ & $140 \pm 1 B$ & $120 \pm 1 B$ & $55 \pm 1 A$ & $68 \pm 1 B$ & $39 \pm 1 A$ & $42 \pm 1 \mathrm{~A}$ \\
\hline $\mathrm{Bb}-19$ & $101 \pm 1 C$ & $160 \pm 2 B$ & $1128 \pm 3 A$ & $147 \pm 1 \mathrm{~A}$ & $15 \pm 1 C$ & $66 \pm 1 \mathrm{C}$ & $17 \pm 1 C$ & $21 \pm 1 \mathrm{C}$ \\
\hline
\end{tabular}

${ }^{\mathrm{a}}$ Values are means of five replicates, ${ }^{\mathrm{b}}$ Standard deviation of the mean, ${ }^{\mathrm{C}}$ Values with the same captital letter are not significantly different between strains, i.e., within the columns at $\mathrm{P}<0.05$

Table 3 : Biomass production of Beauveria bassiana strains and their inhibitory effect of extracellular enzymes against Fusarium oxysporum f.sp. lycopersici

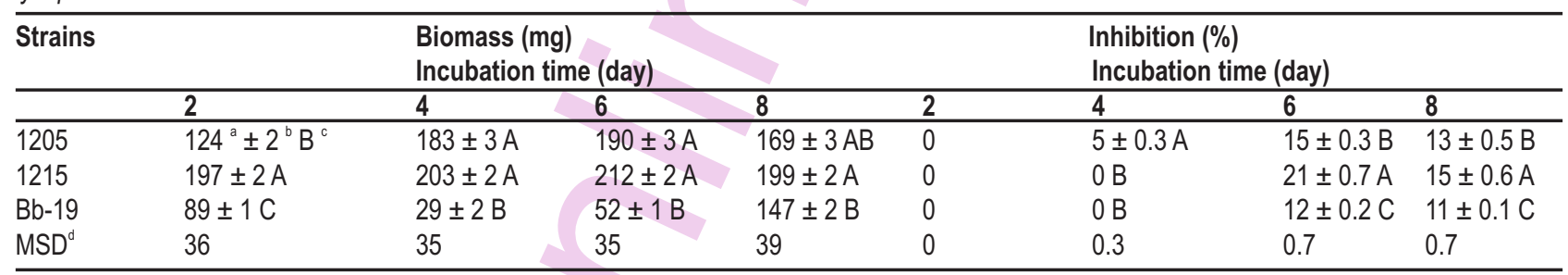

${ }^{a}$ Values are means of five replicates, ${ }^{b}$ Standard deviation of mean values ${ }^{c},{ }^{c}$ Values with the same captital letter are not significantly different between strains, i.e., within the columns at $P<0.05,{ }^{d} M S D$ : Minimum significant difference at $P<0.05$

factor for colonization in to medium or a niche, which determines the efficiency of an antagonist. The growth of $F$. oxysporum was slower when $B$. bassiana strains were inoculated two days before due to the production of diffusible hydrolytic enzymes. Mycoparasites of Trichoderma use the same mechanism when grown together (Annes et al., 2010). Therefore, greater efficiency was achieved by inoculating the antagonist strains two days before the pathogen. Diffusible metabolites of Trichoderma spp., have been found to interact with hyphae of pathogens before direct contact occurred collapsing the mycelia of pathogenic fungus (Zeilinger and Omann, 2007; John et al., 2010). In the present study, the interaction between both organisms occurred $24 \mathrm{hrs}$ before direct contact and was maintained till $48 \mathrm{hrs}$, as determined through stereoscopic microscopy. However, the formation of infection structures by the antagonist, such as appressoria followed by initiation of mycoparasitism that ultimately led to the collapse of the pathogen's mycelia (Zeilinger and Omann, 2007), no formation of infection structure was observed in this study. However, inhibitory diffusible components were produced (Ownley et al., 2008a) and overgrowth of the pathogen by the antagonist is not required to inhibit the fungal pathogen (Gothandapani et al., 2014). 
The production of cell wall degrading enzymes is one of the important aspect involved in the control of phytopathogenic fungi. Most of the phytopathogenic fungi possess cell walls that compromises of chitin, as a structural backbone arranged in regularly ordered layers and $\beta$-1, 3-glucan as a filling material arranged in an amorphous manner (Marcello et al., 2010). This study showed that all $B$. bassiana strains could produce $\beta-1$, 3glucanase and chitinase enzyme (Table 2 ) variably. The strain 1215,1205 and $B b-19$ produced the highest concentration of $\beta-1$, 3 -glucanase to the exent of $167 \pm 2,233 \pm 1$ and $1128 \pm 3$ pkat ml $^{-1}$, respectively on $2^{\text {nd }}, 4^{\text {th }}$ and $6^{\text {th }}$ day, however, the maximum amount of chitinase was produced on $4^{\text {th }}$ day by all the strains. Gomes et al. (2006) reported that generally the maximum amount of enzymes was being produced after 5 to 7 days, which supports the present findings.

The maximum biomass was produced by strain 1215 (212 mg), 1205 (190 mg) and Bb-19 (147 mg) on $6^{\text {th }}$ and $8^{\text {th }}$ day (Table 3). No correlation existed between produced amount of biomass and enzyme. The present results are contradictory with the earlier findings that showed a correlation between the amount of antifungal enzymes produced and biomass of $B$. bassiana (Bark et al., 1996). All B. bassiana strains showed a high percentage of inhibition when their culture filtrates were applied to $F$. oxysporum at 6 days. The highest inhibition was obtained with strain $1215(21 \%)$ and the lowest with strains Bb.19 (12\%) as presented in Table 3. Bark et al. (1996) reported that a culture filtrate of $B$. bassiana when added to different media resulted in $16 \%$ mycelium growth inhibition of $F$. oxysporum f. sp. lycopersici, while in the present study it was $21 \%$. It might be due to enzymatic inducers as they allow the expression of genes involved in production of chitinases and glucanases production.

When $B$. bassiana strain 1215 was tested for its impact on tomato plant by different application methods (Table 4), it was noted that there was no significant difference in plant height stem and foliar application compared to water application, however soil application method showed significant increase. The roots of tomato plants were longer when $B$. bassiana strain 1205 was applied as compared to water. Dry weight of leaves and roots was similar when $B$. bassiana or water was applied as foliar or soil application, but it was lower when $B$. bassiana was injected into the stem compared to water injected plants. Application of antagonistic fungus to soil induced apical and root growth of tomato plants. Schulz and Boyle (2005) reported that this effect might be a response of the plant to endophytic infection. Chowdappa et al. (2013) reported that increase in the vigour of the plant is due to the ability of antagonistic fungus to enhanced production of growth hormones in tomato roots.

Table 4: Effect of Beauveria bassiana strain 1215 on growth parameters of tomato plants after 25 days

\begin{tabular}{lllll}
\hline Treatments & $\begin{array}{l}\text { Plant height } \\
(\mathbf{c m})\end{array}$ & $\begin{array}{l}\text { Root length } \\
(\mathbf{c m})\end{array}$ & $\begin{array}{l}\text { Foliar dry weight } \\
(\mathbf{g})\end{array}$ & $\begin{array}{l}\text { Root dry weight } \\
(\mathbf{g})\end{array}$ \\
\hline Water: soil & $51^{a} \pm 5^{\circ} \mathrm{BC}^{\mathrm{c}}$ & $30 \pm 4 \mathrm{D}$ & $18 \pm 2 \mathrm{ABC}$ & $12 \pm 1 \mathrm{CD}$ \\
Water: foliar & $49 \pm 2 \mathrm{C}$ & $31 \pm 2 \mathrm{D}$ & $17 \pm 3 \mathrm{BC}$ & $13 \pm 2 \mathrm{BC}$ \\
Water: stem & $50 \pm 3 \mathrm{C}$ & $28 \pm 3 \mathrm{E}$ & $16 \pm 3 \mathrm{C}$ & $12 \pm 2 \mathrm{CD}$ \\
B. bassiana: soil & $58 \pm 7 \mathrm{~A}$ & $40 \pm 5 \mathrm{~A}$ & $18 \pm 3 \mathrm{ABC}$ & $13 \pm 2 \mathrm{BC}$ \\
B. bassiana: foliar & $50 \pm 5 \mathrm{C}$ & $35 \pm 3 \mathrm{BC}$ & $19 \pm 3 \mathrm{AB}$ & $14 \pm 3 \mathrm{~B}$ \\
B. bassiana: stem & $51 \pm 6 \mathrm{BC}$ & $34 \pm 3 \mathrm{BC}$ & $13 \pm 2 \mathrm{D}$ & $11 \pm 2 \mathrm{D}$ \\
No pathogen applied & $54 \pm 6 \mathrm{~B}$ & $36 \pm 4 \mathrm{~B}$ & $20 \pm 4 \mathrm{~A}$ & $16 \pm 4 \mathrm{~A}$ \\
MSD $^{\mathrm{d}}$ & 3 & 2 & 2 & 2 \\
\hline
\end{tabular}

${ }^{a}$ Values are means of five replicates, ${ }^{b}$ Standard deviation of mean values, ${ }^{c}$ Values with the same captital letter are not significantly different between strains, i.e. within the columns at $P<0.05,{ }^{d} \mathrm{MSD}$ : Minimum significant difference at $\mathrm{P}<0.05$

Table 5: Antagonistic effect of $B$. bassiana after 25 days of biocontrol test against $F$. oxysporum f.sp. lycopersici

\begin{tabular}{ll}
\hline Treatments & Disease index \\
\hline F. oxysporum + water applied to soil & $2.6 \pm 0.5^{\mathrm{d}}$ \\
F. oxysporum + foliar applied water & $2.2 \pm 0.4^{\text {cd }}$ \\
F. oxysporum + stem applied water & $2.6 \pm 0.4^{\mathrm{d}}$ \\
F. oxysporum + B. bassiana applied to soil & $1.4 \pm 0.5^{\mathrm{b}}$ \\
F. oxysporum + foliar applied B. bassiana & $1.6 \pm 0.5^{\text {bc }}$ \\
F. oxysporum + stem applied B. bassiana & $2.2 \pm 0.4^{\text {cd }}$ \\
No fungal pathogen applied & $0.4 \pm 0.5^{\mathrm{a}}$ \\
\hline
\end{tabular}

* Values are means of four replicate plants per treatment. Values in each columns followed by the same letter are not significantly different according to the Tukey's multiple range test $(\mathrm{P}<0.05)$. Disease was scored on a categorical scale of $0-3$, indicating 0 - healthy plant; 1 - slight infection with yellowing; 2 -severe infection, yellowing and wilting; 3 - death of the plant 
F. oxysporum f. sp. lycopersici race 3 induced vascular wilting on tomato plants in all treatments (Table 5). Application of B. bassiana 1215 reduced the development of disease in tomato plants when applied on the soil surface compared to water application. The severity of disease in tomato plants inoculated with $B$. bassiana was lower than the plants inoculated with water after 25 days. Sangeetha et al. (2013) reported that enzymatic activity and release of metabolites acted directly on the pathogen and/or induced systemic resistance in plants resulting in a decrease in disease development. Sukno et al. (2008) reported that the amount of fungal inoculum used affected the degree of colonization in plants and infection rates. Studies in many plant species have revealed that the enzymatic activity increased as a defence mechanism against environmental stress, such as fungal infection (Jetiyanon, 2007; Shanmugam and Kanoujia, 2011). Regular application of conidial suspension of $B$. bassiana to soil might have reduced the population of $F$. oxysporum $\mathrm{f}$. sp. lycopersici race 3 , which decreased the disease symptoms in tomato plants. However, the fact that disease symptoms were not suppressed completely indicated that growth of the pathogenic fungi was not inhibited completely. Different explanations have been postulated for the continuous presence of phytopathogen. First, survival of $B$. bassiana was lower than that of $F$. oxysporum f. sp. lycopersici, thus antagonist had to be applied regularly to maintain the adequate antagonistic population dynamics. Secondly, application of antagonistic fungus increased the production of plant defence enzymes. $B$. bassiana produces an appressorium to penetrate the insect cuticle and the same process might be involved in the penetration of cuticle of leaf and stem cell wall or roots. This might trigger the production of plant enzymes as a defence mechanism reducing the population of $F$. oxysporumf. sp. lycopersici.

It was concluded that different $B$. bassiana strains in general, and $B$. bassiana strain 1215 in particular, have the ability to control growth of $F$. oxysporum f. sp. lycopersici, and hence they can be used to protect plants against soil borne fungal pathogens. The control of pathogens, however, not only depends on the characteristics of $B$. bassiana strains, but also on the biotic and abiotic factors, which should be considered if antagonists is being planned to use as a biological control strategy.

\section{Acknowledgments}

The research work was funded by project "Infraestructura 251805" from the 'Consejo Nacional de Ciencia y Tecnología (CONACyT), Agua Electron S.A. de C.V. and the 'Instituto Tecnológico de Tuxtla Gutiérrez' (ITTG, TecNM) and Cinvestav (México).

\section{References}

Akello, J., T. Dubois, C.S. Gold, D. Coyne, J. Nakavuma and P. Paparu: Beauveria bassiana (Balsamo) Vuillemin as an endophyte in tissue culture banana (Musa spp.). J. Invertebr. Pathol., 96, 34-42 (2007).
Ahmed Idris, H., N. Labuschagne and L. Korsten: Screening rhizobacteria for biological control of Fusarium root and crown rot of sorghum in Ethiopia. Biol. Control., 40,97-106 (2007).

Annes, M., A. Tronsmo, V. Edel-Hermann, L.G. Hjeljord, C. Héraud and C. Steinberg: Characterization of field isolates of antagonistic against. Fungal Biol-UK., 114, 691-701 (2010).

Bark, Y.G., D.G. Lee, Y.H. Kim and S.C. Kang: Antibiotic properties of an entomopathogenic fungus, Beauveria bassiana, on Fusarium oxysporum and Botrytis cinerea. Korean J. Plant Pathol., 12, 245250 (1996)

Barone, A. and L. Frusciante: Marker-assisted selection: current status and future perspectives in crops, livestock, forestry and fish (Eds.: E.P. Guimaraes, J. Ruane, B.D. Scherf, A. Sonnino and J.D. Dargie). Food and Agriculture Organization of the United Nations, Rome, Italy, pp. 151-164 (2007).

Brownbridge, M., S.D. Reay, T.L. Nelson and T.R. Glare: Persistence of Beauveria bassiana (Ascomycota: Hypocreales) as an endophyte following inoculation of radiata pine seed and seedling. Biol. Control, 61, 194-200 (2012).

Chandel, S., E.J. Allan and S. Woodward: Biological control of Fusarium oxysporum f. sp. Iycopersici on tomato by Brevibacillus brevis. J. Phytopathol., 158, 470-478 (2010).

Chowdappa, P., S.P. Mohan Kumar, M. Jyothi Lakshmi and K.K. Upetri: Growth stimulation and induction of systemic resistance in tomato against early and late blight by Bacillus subtilis OTPB1 or Trichoderma harzianum OTPB3. Biol. Control, 65, 109-117 (2013).

Dean, R., J.A.L. Van Kan, Z.A. Pretorius, K.E. Hammond-Kosack, A. Di Pietro, P.D. Spanu, J.J. Rudd, M. Dickman, R. Kahmann, J. Ellis and G.D. Foster: The top 10 fungal pathogens in molecular plant pathology. Mol. Plant Pathol., 13, 414-430 (2012).

Dubey, S., M. Suresh and B. Singh: Evaluation of species against f. sp. for integrated management of chickpea wilt.. Biol. Control, 40, 118-127 (2007)

Flori, P. and R. Roberti: Treatment of onion bulbs with antagonistic fungi for the control of Fusarium oxysporum $\mathrm{f} s p$. cepae. Difesa delle Piante., 16, 5-12(1993).

Gomes, I., S. Mohammad, R.R. Sabita and J.G. Donald: Comparative studies on production of cell wall-degrading hydrolases by Trichoderma reesei and $T$. viride in submerged and solid-state cultivations. Bangladesh J. Microbiol., 23, 149-155 (2006).

Gothandapani, S., G. Boopalakrishnan, N. Prabhakaran, B.S. Chethana, M. Aravindhan, M. Saravanakumar and G. Ganeshan: Evaluation of entomopathogenic fungus against Alternaria porri (Ellis) causing purple blotch disease of onion. Arch Phytopathol. Plant Protect., 48, 135-144 (2014).

Greenfield, M., M.I. Gómez-Jiménez, V. Ortiz, F.E. Vega, M. Kramer and S. Parsa: Beauveria bassiana and Metarhizium anisopliae endophitically colonize cassava roots following soil drench inoculation. Biol. Control, 95, 40-48 (2016).

Gurulingappa, P., G.A. Sword, G. Murdoch and P.A. McGee: Colonization of crop plants by fungal entomopathogens and their effects on two insect pests when in plant. Biol. Control, 55, 34-41 (2010).

INEGI. Internet Resource. http://www.inegi.org.mx (accessed 12.03.15) (2011).

Jetiyanon, K.: Defensive-related enzyme response in plants treated with a mixture of Bacillus strains (IN937a and IN937b) against different pathogens. Biol. Control, 42, 178-185(2007).

John, R.P., R.D. Tyagi, D. Prévost, S.K. Brar, S. Pouleur and R.Y. 
Surampalli: Mycoparasitic Trichoderma viride as a biocontrol agent against Fusarium oxysporum f. sp. adzuki and Pythium arrhenomanes and as a growth promoter of soybean. Crop Prot., 29, 1452-1459 (2010).

Lopez, D.C. and G.A. Sword: The endophytic fungal entomopathogens Beauveria bassiana and Purpureocillium lilacinum enhance the growth of cultivated cotton (Gossypium hirsutum) and negatively affect survival of the cotton bollworm (Helicoverpa zea). Biol. Control, 89, 53-60 (2015).

Marcello, C.M., A.S. Steindorff, S.P. Silva, R.N. Silva, L.A.M. Bataus and C.J. Ulhoa: Expression analysis of the exo- $\beta-1,3-$ glucanase from the mycoparasitic fungus Trichoderma asperellum. Microbiol. Res., 165, 75-81 (2010).

Mbarga, J.B., G. Martijn Ten Hoopen, J. Kuaté, A. Adiobo, M.E.L. Ngonkeu, Z. Ambang, A. Akoa, P.R. Tondje and B.A.D. Begoude: Trichoderma asperellum: A potential biocontrol agent for Pythium myriotylum, causal agent of cocoyam (Xanthosoma sagittifolium) root rot disease in cameroon. Crop Prot., 36, 18-22 (2012).

Montes-Molina, J.A., I.H. Nuricumbo-Zarate, J. Hernández-Díaz, F.A. Gutiérrez-Miceli, L. Dendooven and V.M. Ruíz-Valdiviezo: Characteristics of tomato plants treated with leaf extracts of neem (Azadirachta indica A. Juss. (L.)) and mata-raton (Gliricidia sepium (Jacquin)): A greenhouse experiment. J. Environ. Biol., 35, 935$942(2014)$.

Nirmaladevi, D., M. Venkataramana, R.K. Srivastava, S.R. Uppalapati, V.K. Gupta, T. Yli-Mattila, K.M. Clement Tsui, C. Srinivas, S.R. Niranjana and N.S. Chandra: Molecular phylogeny, pathogenicity and toxigenicity of Fusarium oxysporum f. sp. lycopersici. Sci. Rep-UK., 6, 21367 (2016).

Ownley, B.H., R.M. Pereira, W.E. Klingeman, N.B. Quigley and B.M. Leckie: Beauveria bassiana, a dual purpose biocontrol organism, with activity against insect pest and plant pathogens (Eds.: R.T. Lartey and A.J. Caesar). Emerging Concepts in Plant Health Management. Research Signpost, Kerala, India, pp. 256-269 (2004).

Ownley, B.H., M.M. Dee and K.D. Gwinn: Effect of conidial seed treatment rate of entomopathogenic Beauveria bassiana 11-98 on endophytic colonization of tomato seedlings and control of Rhizoctonia disease. Phytopathology, 98, S118 (2008a).

Ownley, B.H., M.R. Griffin, W.E. Klingeman, K.D. Gwinn, J.K. Moulton and R.M. Pereira: Beauveria bassiana: endophytic colonization and plant disease control. J. Invertebr. Pathol., 3, 267-70 (2008b).

Posada, F.J. and F.E. Vega: Establishment of the fungal entomopathogen Beauveria bassiana (Ascomycota: Hypocreales) as an endophyte in cocoa seedlings (Theobroma cacao). Mycologia, 97, 1195-2000 (2005).

Posada, F.J., M.A. Aime, S.W. Peterson, S.A. Rehner and F.E. Vega: Inoculation of coffee plants with the fungal entomopathogen Beauveria bassiana (Ascomycota: Hypocreales). Mycol. Res.,
$111,748-57$ (2007)

Prapagdee, B., K. Kotchadat, A. Kumsopa and N. Visarathanonth: The role of chitosan in protection of soybean from sudden death syndrome caused by Fusarium solani f. sp. glycines. Biores. Technol., 98, 1353-8 (2007).

Quesada-Moraga, E., F.J. Munoz-Ledesma and C. Santiago-Alvarez: Systemic protection of Papaver somniferum L. against Iraella luteipes (Hymenoptera: Cynipidae) by an endophytic strain of Beauveria bassiana (Ascomycota: Hypocreales). Environ. Entomol., 38, 723-730 (2009).

Rajeswari, P.: In vitro inhibition of pectinolytic enzymes of Fusarium oxysporum by Trichoderma spp. and Pseudomonas fluorescens on Arachis hypogaea L. Int. J. Curr. Microbiol. App. Sci., 4, 604$613(2015)$.

Rahman, M.A., M.F. Begum and M.F. Alam: Screening of Trichoderma isolates as a biological control agent against Ceratocystis paradoxa causing pineapple disease of sugarcane. Mycobiology, $4,277-285(2009)$.

Reissig, J.L., J.L. Strominger and L.F. Leloir: A modified colorimetric method for the estimation of $\mathrm{N}$-acetylamino sugars. J. Biol. Chem., 217, 959-966 (1957).

Sangeetha, G., R. Thangavelu, S. Usha Rani and A. Muthukumar: Antimicrobial activity of medicinal plants and induction of defense releated compounds in banana fruits $\mathrm{cv}$. Robusta against crown rot pathogens. Biol. Control, 64, 16-25 (2013).

Schulz, B. and C. Boyle: The endophytic continuum. Mycol. Res., 109, 661-686 (2005).

Shanmugan, V. and N. Kanoujia: Biological management of vascular wilt of tomato caused by Fusarium oxysporum f. sp. Iycopersici by plant growth promoting rhizobacterial mixture. Biol. Control, 57, 85-93 (2011).

Sukno, S.A., V.M. García, B.D. Shaw and M.R. Thon: Root infection and systemic colonization of maize by Colletotrichum graminicola. App. Environ. Microbiol., 74, 823-832 (2008).

Sung, G.H., N.L. Hywel-Jones, J.M. Sung, J.J. Luangsa-ard, B. Shrestha and J.W. Spatafora: Phylogenetic classification of Cordyceps and the clavicipitaceous fungi. Stud. Mycol., 57, 5-59 (2007).

Vesely, D. and D. Koubova: In vitro effect of the entomopathogenic fungi Beauveria bassiana (Bals.-Criv.) Vuill. and B. brongniartii (Sacc.) Petch on phytopathogenic fungi. Ochr. Rostl., 30, 113-120 (1994).

Vos, C.M., Y. Yang, B. De Coninck and B.P.A. Cammue: Fungal (-like) biocontrol organisms in tomato disease control. Biol. control, 74, 65-81 (2014).

Zeilinger, S. and M. Omann: Trichoderma Biocontrol: Signal transduction pathways involved in host sensing and mycoparasitism. Gene Regul. Syst. Biol., 1, 227-234 (2007).

Zheng, Y. and C.C. Wozniak: Adaptation of a beta-1, 3-glucanase assay to microplate format. Biotechniques, 22, 922-926 (1997). 